\title{
Biotechnological Potentialities and Valorization of Mango Peel Waste: A Review
}

(Potensi Bioteknologi dan Penaikan Harga Sisa Kulit Mangga: Suatu Ulasan)

\author{
PRAdeEP Puligundla, Vijaya SARATHi Reddy ObUlam, SANG Eun OH* \& \\ CHULKYOON MOK
}

\begin{abstract}
In recent years, by-products of fruit processing have received a great deal of attention, which is primarily due to their nutritional and economic exploitation through utilization of emerging technologies. Mango peel waste, a by-product from pulp processing units, is an important source of high quality antioxidant dietary fibre, pectin, polyphenols and carotenoids . It also possess significant biotechnological potential since it has been found suitable for several bioprocesses including ethanol, biogas, lactic acid, enzymes and single cell production. Valorization of mango peel through different routes not only can increase the profitability of fruit processing industries, but also help reduce environmental pollution. This review intends to provide a broad view on available technologies for mango peel waste utilization, with an emphasis on its biotechnological conversion into added value products beside other ways of utilization.
\end{abstract}

Keywords: Biotechnological potential; functional food; Mango peel waste; valorization

\section{ABSTRAK}

Sejak kebelakangan ini, hasil sampingan pemprosesan buah-buahan telah menerima banyak perhatian, terutamanya disebabkan oleh khasiat dan eksploitasi ekonomi melalui penggunaan teknologi baru. Sisa kulit mangga, hasil sampingan daripada pulpa pemprosesan unit, adalah merupakan sumber antioksidan berkualiti tinggi diet serat, pektin, polifenol dan karotenoid. Ia juga memiliki potensi bioteknologi yang besar kerana didapati sesuai untuk beberapa bioproses termasuk etanol, biogas, asid laktik, enzim dan pengeluaran sel tunggal. Penaikan harga sisa kulit mangga melalui pelbagai cara bukan sahaja boleh meningkatkan keuntungan industri pemprosesan buah-buahan, tetapi juga membantu mengurangkan pencemaran alam sekitar. Kajian ini bertujuan memberikan pandangan yang luas mengenai teknologi terkini untuk penggunaan sisa kulit mangga, dengan penekanan kepada penukaran bioteknologi produk tambah nilai selain daripada cara penggunaan lain.

Kata kunci: Bioteknologi; makanan fungsian; penaikan harga potensi; sisa kulit mangga

\section{INTRODUCTION}

Mango (Mangifera indica Linn.) is one of the important tropical fruits that usually found in Southern Asia (Eastern India, China, Thailand, Pakistan, Burma, Andaman Islands) and Central America. Mango trees are grown vastly in many tropical regions of the world. Mango fruit is extensively used for food, juice, flavor, fragrance and coloring purposes (Kittiphoom 2012). The period of development from flowering to fruit maturity is between 3-6 months depending on the cultivar, the size and color of ripe fruit. For year 2011, India is the largest mango producer in the world, with 15188000 tonnes (http:// www.mapsofworld.com). Several varieties of mango are grown in India, which include Banganapalli, Suvarnarekha, Neelum, Totapuri, Kesar, Alphonso, Rajapuri, Jamadar, Chausa, Dashehari, Fazli, Gulabkhas, Kishen Bhog, Himsagar, Zardalu and Langra (www.apeda.gov.in). Ripe mangoes are processed into pulps, purees, jams and jellies, frozen mango products, canned products and dehydrated products (Berardini et al. 2005; Ramteke \& Eipeson 1997). Nutritionally, mangoes are a good source of vitamins A, C,
B6 and pigment antioxidants-carotenoids. Also, rich source of polyphenols and fiber. After pulp extraction from fruit (mesocarp part), peel and kernel are discarded as waste and becoming a source of pollution (Puravankara et al. 2000); they account for $35-55 \%$ of the fruit (Bhalerao et al. 1989) as shown in Table 1, depending on the variety.

\section{MANGo PeEl Chemical Composition}

Fresh mango peel contains significant amount of moisture. Mango peel is rich in pectin, cellulose, hemicelluloses, lipids, proteins, polyphenols and carotenoids (Ajila et al. 2007). In general, the level of reducing sugars, nonreducing sugars, protein and cellulose varies depending on cultivar. Typical composition of fresh and dried mango peel is given in Table 2 .

The dried mango peel contains high amounts of reducing sugars. Therefore, it can be used as substrate for fermentative production of ethanol, organic acids and other industrial bioproducts. In recent years, this fruit processing waste has received much attention as a potential source of 
TABLE 1. Different components obtained during mango pulp extraction

\begin{tabular}{lc}
\hline Component & Percentage \\
\hline Mango pulp & $45-65$ \\
Peels & $15-20$ \\
Pulpier waste & $15-20$ \\
Stones & $10-20$ \\
\hline
\end{tabular}

(Source: Central Food Technological Research Institute, 1985)

TABLE 2. Average composition (\%) of fresh and dried mango peel (Reddy et al. 2011)

\begin{tabular}{lcc}
\hline Content & Fresh mango peel & Dried mango peel \\
\hline Moisture & 70 & 10 \\
Total solids & 25 & 70 \\
Reducing sugars & 7 & 30 \\
Non-reducing sugars & 5 & 4 \\
Protein & 3.5 & 4 \\
Cellulose and lignin & 25 & 23 \\
\hline
\end{tabular}

bio-energy and other value-added products. Value addition can be successfully achieved through biotechnological route.

\section{PROBLEM OF WASTE DisPosAL}

Disposal of wastes from fruit-canning industries has been a problem due to high transportation costs and limited availability of landfills, as these by-products carry no commercial value, they are often disposed unscrupulously. Improper disposal of mango peel waste may appreciably increase the environmental pollution due to its rapid decay, eventually becoming a source of insect multiplication. A high level of BOD and COD in mango peel waste create a further problem in disposal. To a certain extent, vermicomposting technology could help the disposal of organic industrial wastes, including fruit waste, in a safe, economic and useful manner. However, valorization through different techniques will certainly eliminate the disposal problem.

\section{BIOTECHNOLOGICAL PotentiaLITIES}

\section{PRODUCTION OF ETHANOL}

Mango peel extract has been used for bioethanol production. Direct fermentation, without nutrient addition, yielded $5.13 \%(\mathrm{w} / \mathrm{v})$ ethanol; however, upon supplementation with yeast extract, peptone and wheat bran, final ethanol yield was increased by nearly $40 \%$, i.e. $7.14 \%$ (w/v) (Reddy et al. 2011). This enhancement could be due to availability of sufficient nitrogen and other yeast nutrients in the supplemented medium since the mango peel contain scarce amount of protein. Mango peel bioethanol is economically and environmentally viable and can be a good substitute of petrol (Walia et al. 2013). Fruit processing wastes can be used as potential feedstock for bioethanol production and this could also be an attractive alternate for disposal of the polluting residues (Wyman 2001). Arumugam and Manikandan (2011) reported 9.68\% ethanol yield using mango peel, however the yield and productivity was relatively low compared with mango pulp ethanol fermentation. Thermotolerant and alcohol tolerant yeasts, which are able to grow at $40^{\circ} \mathrm{C}$, have been used for ethanol production from mango peel; a maximum ethanol concentration of $13 \mathrm{~g} / \mathrm{L}$ was observed at $120 \mathrm{~h}$ (Somda et al. 2011).

\section{EFFECT OF PRETREATMENT ON ETHANOL YIELD}

Reddy et al. 2011 have reported enhanced yield of reducing sugars from pectinase treated mango peel. In this study, higher levels of solubilization of reducing sugars $(30 \% \mathrm{w} / \mathrm{v})$ was observed with crude pectinase treatment compared to simple aqueous extraction $(20 \% \mathrm{w} / \mathrm{v})$, in $24 \mathrm{~h}$ enzyme reaction time. Since mango peel is a rich source (10-15\%) of pectin, a complex set of polysaccharides, pectinase treatment can be effective for release of fermentable sugars. Saravanan et al. (2012) have suggested alkaline pretreatment to decrease the crystallinity of mango peel and for simultaneous removal of lignin and other inhibitors. For pretreatment, $2 \% \mathrm{NaOH}$ was added and autoclaved at $121^{\circ} \mathrm{C}$ for $30 \mathrm{~min}$ and excess alkali was neutralized with phosphoric acid.

\section{WINE FERMENTATION}

Mango wine fermentation using yeast-mango peel immobilized biocatalyst system has been reported recently (Varakumar et al. 2012). The operational stability of the biocatalyst system was found to be good with better ethanol productivities (1.53-3.29 g/L/h) and it can also be suitable for low temperature winemaking. The overall improved quality of wines has been noted using this system. 


\section{ENZYMES PRODUCTION}

Mango peel at the level of $7 \%(\mathrm{w} / \mathrm{v})$ has been used for carboxymethyl cellulose (CMCase) production using Paenibacillus polymyxa (Kumar et al. 2012a). Mango peel has been used for the production of cellulase enzyme (Saravanan et al. 2012) and a maximum cellulase activity of $7.8 \mathrm{IU} / \mathrm{mL}$ was reported under optimized conditions.

\section{LACTIC ACID FERMENTATION}

Potential of mango peel as a low cost substrate for the production of lactic acid has been investigated (Jawad et al. 2013). In this study, mango peel was directly fermented using bacteria having both amylolytic and lactic acid producing capabilities. A maximum production of $17.484 \mathrm{~g} / \mathrm{L}$ lactic acid was obtained through statistical optimization of fermenting conditions. The mesophilic microbial system, which can operate at $35^{\circ} \mathrm{C}$, that has been used in this study seems to have practical advantage because of low cost and therefore method is economically viable. In another study, lactic acid concentration of $63.33 \mathrm{~g} / \mathrm{L}$ was obtained from mango peels fermentation by Lactobacillus casei (Mudaliyar et al. 2012). This increment in the final lactic acid concentration was due to the steam explosion pretreatment followed by acid hydrolysis of peel waste before fermentation, compared with the previous report. Therefore, pretreatment and hydrolysis before fermentation play a key role in the yield of lactic acid as these steps increase total fermentable sugars in the medium.

\section{PECTINASES PRODUCTION}

Pectinases production using mango peel as substrate has been reported (Kumar et al. 2012b). As mango peel rich in pectin, microorganisms (especially filamentous fungi) which are capable of degrading pectin can be used for fermentative production of pectinases. In this study, Aspergillus foetidus was used to produce polygalacturonase and pectin lyase using Totapuri mango peel and highest productivity was observed with solid state fermentation.

\section{BIOGAS PRODUCTION}

Anaerobic digestion has been widely used for the treatment of organic industrial wastes and agricultural wastes including fruit processing wastes. Mango peel has been used for biogas production; gas production at a level of $0.33 \mathrm{~m}^{3}$ biogass $/ \mathrm{Kg}_{\mathrm{TS}}$ with $53 \%$ methane content at hydraulic retention time (HRT) of 15 days has been reported (Somayaji et al. 2001). Ensilage of mango peel for 6 months has been shown to aid in the better conversion of major components of its carbohydrates into volatile fatty acids. This pretreatment effect has resulted in $58 \%$ more gas production as compared with control (Madhukara et al. 1993). Microbiological pretreatment of mango peel for 6 days was shown to increase the total gas production by 8 -fold (Devi \& Nand 1989). In a recent study, a higher specific gas production was observed for mango peel, co-digestion with cow dung at ratio of $1: 10$ and at $8 \%$ TS, compared with controls (Anhuradha \& Mullai 2010).

\section{SINGLE CELL PROTEIN PRODUCTION}

Mango-peel extract has been used for single cell protein production using Pichia pinus yeast. In this study, a maximum yield of $6.2 \mathrm{~g} / \mathrm{L}$ was observed at the third day of growth and cells contained $62.2 \%$ crude protein, $39 \%$ true protein and $12.9 \%$ nucleic acids (Rashad et al. 1990).

\section{NUTRITIONAL VALORIZATION}

\section{SOURCE OF PECTIN}

Mango peel is a good source of pectin i.e. around 10$15 \%$. A maximum pectin yield of $21 \%$ was obtained by soaking finely ground defatted mango peels in sulphuric acid solution $\left(\mathrm{pH} 2.5\right.$ at $80^{\circ} \mathrm{C}$ for $120 \mathrm{~min}$ ) (Rehman et al. 2004). A pectin level of around $18 \%$ was reported in Totapuri mango peel (Kumar et al. 2012b). Mango peel pectins exhibited better gelling capacity than commercial citrus pectin (Koubala et al. 2012).

\section{ANIMAL FEED}

Mango byproducts can be used as livestock feed (de la Cruz Medina \& Garcia 2002; Sruamsiri \& Silman 2009) as they have a higher energy value than maize silage and could partly replace energy concentrations in diets for ruminants (Azevêdo et al. 2011). Mango peels are especially palatable to ruminants because of their high sugar content. A recent study showed that mango peels have promising potential for utilization as feed or feed additives due to their in vitro digestibility, chemical composition and favorable volatile fatty acid (VFA) composition and have the potential to attenuate rumen methanogenesis, thereby greenhouse gas emissions (methane) can be reduced (Geerkens et al. 2013). However, high moisture and acidity of fresh peels may limit their use (Sruamsiri \& Silman 2009). In addition, supplementation of nitrogen or protein source to peels is necessary to allow an efficient utilization of energy since they contain low protein. Fermentation can greatly influence the nutritional composition of mango peels. An increase in the protein content and a decrease in the levels of antinutrients such as tannins and phytate were observed upon fermentation of the ripe mango peels (Ojokoh 2007). In addition, fermentation enhances the nutrient, vitamins, essential amino acids and fibre digestibility. Low quality of non fermented agro-byproducts can be upgraded after fermentation with selective microorganisms and such fermented products could be used as healthy animal feed.

\section{PHENOLIC ANTIOXIDANTS}

Mango peel is a rich source of phenolic compounds, which exhibit antioxidant activity (Palmeira et al. 2012). In addition, phenolic compounds also have antiviral, 
antibacterial and anti-inflammatory activity (Zgórka \& Kawka 2001). The major phenolic compounds present in mango peel extract are reported to be syringic acid, quercitin, mangiferin pentoside and ellagic acid (Ajila et al.2010a). Peels are good source of mangiferin (C-glucosyl xanthone), a heat-stable and pharmacologically active phytochemical. Mangiferin possess various bioactivities, such as antiinflammation, anti-diabetic, immunomodulatory, antitumor and antioxidant (Luo et al. 2012). It showed high $\mathrm{DPPH}^{\cdot}$ free-radical scavenging capacity and thus has potential in the prevention of oxidative stress-associated diseases. Polyphenol rich fractions of peel extract could be used as natural antioxidants and functional food or feed supplements (Berardini et al. 2005). In a recent study, phenolic compounds from mango peels were successfully extracted using subcritical water (SCW) and this solvent is considered to be environmentally friendly for extraction of bioactive compounds (Tunchaiyaphum et al. 2013). The subcritical water extraction is considered to be timesaving, results in high yield and no toxic solvent residues yielding method and therefore can be applicable for the food industry.

\section{FUNCTIONAL FOOD INGREDIENT}

Mango peel flour can be used as a functional ingredient in developing healthy food products such as noodles, bread, biscuits, sponge cakes and other bakery products (Aziz et al. 2012). As mango peel is rich in source of polyphenols, carotenoids and vitamins with different health-promoting properties, there is enormous potential for developing functional foods based on mango peel. The solubility, water and oil absorption values of mango peel powders play key role for their utilization in foods. Different drying methods influence the functionality of mango peel. The cabinet dehydration method was found better over other drying methods in mango peel powder preparation, which intended for utilization in several food applications (Sogi et al. 2013). In a study, yogurt made with supplementation of $10 \%$ of mango peel powder showed a good texture, flavour and color characteristics and exhibited one month shelf life without adding preservatives (Ruiz et al. 2011).

\section{DIETARY FIBRE}

Dietary fibres and phytochemicals are gaining increased attention because of their antioxidant, anticarcinogenic and other health benefiting properties (Hertog et al. 1993). Mango peel fiber with high hydration capacities has potential in dietary fibre-rich foods preparation (Koubala et al. 2013). Mango peel dietary fibre has been shown to be associated with natural antioxidant components and therefore its antioxidant capacity is greater than that of DL- $\alpha$-tocopherol and French Paradoxe (Larrauri et al. 1997). A recent study indicated the presence of significant amount of bound phenolics in dietary fibre, which adds additional health benefits of antioxidant property (Ajila \& Prasada Rao 2013). Mango peel powder incorporation has increased the total dietary fiber content of macaroni significantly, from $8.6 \%$ in control to $17.8 \%$ in $7.5 \%$ peel powder incorporated macaroni and therefore it can be utilized for the preparation of macaroni with improved nutritional properties (Ajila et al. 2010b). In another study, beef burger samples incorporated with $3 \%$ level of mango peel dietary fiber exhibited satisfactory quality grade for all characteristics (Abdeldaiem \& Hoda 2012).

\section{RICH SOURCE OF CAROTENOIDS}

Mango has been reported to contain high amounts of carotenoids (Chen et al. 2004). Carotenoids content is high in peel with advance physiological ripening compared with the peel with partial ripening (Ajila et al. 2007; Varakumar et al. 2011). Mango carotenoids have been shown to possess high vitamin A activity and antioxidative capacity, owing to its high beta-carotene content (Mercadante \& Rodriguez-Amaya 1998).

\section{OTHER VALORIZATION ROUTES}

\section{REMOVAL OF HEAVY METALS}

Mango peel was used as biosorbent for the removal of $\mathrm{Cd}(\mathrm{II})$ and $\mathrm{Pb}(\mathrm{II})$ heavy metals from aqueous solution (Iqbal et al. 2009a). A fast biosorption rates i.e. reaching at equilibrium in $60 \mathrm{~min}$, for both metals have been observed in this study and the mode of sorption was found to be ion exchange using X-ray spectroscopy (EDX). In a similar study, effective removal of $\mathrm{Cu}^{2+}, \mathrm{Ni}^{2+}$ and $\mathrm{Zn}^{2+}$ from constituted metal solutions and genuine electroplating industry wastewater was observed using mango peel waste (Iqbal et al. 2009b).

\section{SOURCE OF ANTIMICROBIAL COMPOUNDS}

Strong antifungal activities against pathogenic fungus such as Rhizoctonia solani Kühn and Rhizoctonia cerealis vander Hoven have been reported with ethyl acetate fraction and ethanol crude extracts of mango peel (Qin et al. 2007a). However, in case of unripe mango peel, superior fungal inhibition was observed with $95 \%$ methanol extract than $95 \%$ ethanol extract and the inhibition of methylene chloride extract was greater than ethyl acetate (Qin et al. 2007b). The major component for antifungal activity was found to be 5- (12-heptadeconyl)-resorcinol (Cojocaru et al. 1986).

\section{PHARMACEUTICAL EXCIPIENT}

Mango peel derived pectin can be used as pharmaceutical excipient to prepare solid oral dosage form (Malviya \& Kulkarni 2012). In a similar study, suitability of mango peel pectin as a super disintegrating agent has been tested (Malviya et al. 2010). The results of this study showed that mango peel pectin has relatively lesser drug release capacity compared to sodium starch glycolate; however, due to its good solubility in biological fluid and better 
swelling index, it can be used to prepare fast dispersible tablets.

\section{CONCLUSION}

Mango peel waste contains many nutritionally and economically valuable components. The wastes from mango pulp processing industries have significant exploitation potential. In recent years, mango peel dietary fibre has received a great deal of attention as functional food ingredient. The presence of associated phenolic compounds provides the peel fibre material with intrinsic antioxidant capacity. Therefore, it is capable of offering low-cost nutritional dietary supplement for lower income masses. Economic valorization of peel wastes could readily be realized through biotechnological utilization. Thus, through biotechnology route, environmentally polluting by-products of mango processing industry could be converted into products with a great economic importance. By using novel scientific and technological methods for extraction and processing, valuable products from mango peel could be obtained. Further technological developments in that direction are highly warranted.

\section{REFERENCES}

Abdeldaiem, M.H. \& Hoda, G.M.A. 2012. Use of irradiated mango (Mangifera indica) peels powder as potential source of dietary fiber and antioxidant in beef burger. Journal of Applied Sciences Research 8: 3677-3687.

Ajila, C.M. \& Prasada Rao, U.J.S. 2013. Mango peel dietary fibre: Composition and associated bound phenolics. Journal of Functional Foods 5: 444-450.

Ajila, C.M., Aalami, M., Leelavathi, K. \& Prasada Rao, U.J.S. 2010b. Mango peel powder: A potential source of antioxidant and dietary fiber in macaroni preparations. Innov. Food Sci. Emerg. 11: 219-224.

Ajila, C.M., Jaganmohan Rao, L. \& Prasada Rao, U.J.S. 2010a. Characterization of bioactive compounds from raw and ripe Mangifera indica L. peel extracts. Food Chem. Toxicol. 48: 3406-3411.

Ajila, C.M., Bhat, S.G. \& Prasada Rao, U.J.S. 2007. Valuable components of raw and ripe peels from two Indian mango varieties. Food Chem. 102: 1006-1011.

Anhuradha, S. \& Mullai, P. 2010. Mesophilic biodigestion of cow dung and mango peel in relation to bioenergy - Batch study. Environmental Science: An Indian Journal 5: 320-324.

Arumugam, R. \& Manikandan, M. 2011. Fermentation of pretreated hydrolyzates of banana and mango fruit wastes for ethanol production. Asian J. Exp. Biol. Sci. 2: 246-256.

Azevêdo, J.A.G., Valadares Filho, S.deC., Pina, D.dosS., Detmann, E., Valadares, R.F.D., Pereira, L.G.R., Souza, N.K.de P. \& Costa e Silva, L.F. 2011. Intake, total digestibility, microbial protein production and the nitrogen balance in diets with fruit by-products for ruminants. Rev. Bras. Zootec. 40: 1052-1060.

Aziz, N.A.A., Wong, L.M., Bhat, R. \& Cheng, L.H. 2012. Evaluation of processed green and ripe mango peel and pulp flours (Mangifera indica var. Chokanan) in term of chemical composition, antioxidant compounds and functional properties. J. Sci. Food Agr. 92: 557-563.
Berardini, N., Knodler, M., Schieber, A. \& Carle, R. 2005. Utilization of mango peels as a source of pectin and polyphenolics. Innov. Food Sci. Emerg. 6: 442-452.

Bhalerao, S.D., Mulmuley, G.V., Anathakrishna, S.M. \& Potty, V.H. 1989. Wash and waste water management in food industry. Fruit and vegetable processing. Indian Food Packer 43: 5-11.

Central Food Technological Research Institute (CFTRI). 1985. Mango pulp concentration, Mysore, India. pp. 25-39.

Chen, J.P., Tai, C.Y. \& Chen, B.H. 2004. Improved liquid chromatographic method for determination of carotenoids in Taiwanese mango (Mangifera indica L.). J. Chromatogr. A 1054: 261-268.

Cojocaru, M., Droby, S., Glotter, E., Goldman, A., Gottlieb, H.E., Jacoby, B. \& Prusky, D. 1986. 5- (12-heptadeconyl)resorcinol, the major component of the antifungal activity in the peel of mango fruit. Phytochemistry 25: 1093-1095.

de la Cruz Medina, J. \& Garcia, H.S. 2002. Mango: Postharvest operations. In Compendium on Post-harvest Operations, edited by Mejia, D. \& Lewis, B. AGSI/FAO.

Devi, S.S. \& Nand, K. 1989. Microbial pretreatment of mango peel for biogas production. J. Microb. Biotechnol.4: 110-115.

Geerkens, C.H., Schweiggert, R.M., Steingass, H., Boguhn, J., Rodehutscord, M. \& Carle, R. 2013. Influence of apple and citrus pectins, processed mango peels, a phenolic mango peel extract, and gallic acid as potential feed supplements on in vitro total gas production and rumen methanogenesis. J. Agric. Food Chem. 61: 5727-5737.

Hertog, M.G.L., Feskens, E.J.M., Hallman, P.C.H., Katan, M.B. \& Kromhout,D. 1993. Dietary antioxidant flavonoids and risk of coronary heart disease: The Zutphen Elderly Study. Lancet 342: 1007-1014.

Iqbal, M., Saeed, A. \& Zafar, S.I. 2009a. FTIR spectrophotometry, kinetics and adsorption isotherms modelling, ion exchange, and EDX analysis for understanding the mechanism of $\mathrm{Cd}^{2+}$ and $\mathrm{Pb}^{2+}$ removal by mango peel waste. J. Haz. Mater. 164: 161-171.

Iqbal, M., Saeed, A. \& Kalim, I. 2009b. Characterization of adsorptive capacity and investigation of mechanism of $\mathrm{Cu}^{2+}$, $\mathrm{Ni}^{2+}$, and $\mathrm{Zn}^{2+}$ adsorption on mango peel waste from constituted metal solution and genuine electroplating effluent. Separ. Sci. Technol. 44: 3770-3791.

Jawad, A.H., Alkarkhi, A.F.M., Jason, O.C., Easa, A.M. \& Norulaini, N.A.N. 2013. Production of lactic acid from mango peel waste-factorial experiment. Journal of King Saud University-Science 25: 39-45.

Kittiphoom, S. 2012. Utilization of Mango seed. International Food Research Journal 19: 1325-1335.

Koubala, B.B., Kansci, G., Garnier, C., Thibault, J.F. \& Ralet, M.C 2013. Physicochemical properties of dietary fibres prepared from ambarella (Spondias cytherea) and mango (Mangifera indica) peels. Food Bioprocess Tech. 6: 591-597.

Koubala, B.B., Kansci, G., Garnier, C., Ralet, M.C. \& Thibault, J.F. 2012. Mango (Mangifera indica) and Ambarella (Spondias cytherea) peel extracted pectins improve viscoelastic properties of derived jams. African Journal of Food, Agriculture, Nutrition and Development 12: 6200-6212.

Kumar, D., Ashfaque, M., Muthukumar, M., Singh, M. \& Garg, N. 2012. Production and characterization of carboxymethyl cellulase from Paenibacillus polymyxa using mango peel as substrate. J. Environ. Biol. 33: 81-84.

Kumar, Y.S., Kumar, P.V. \& Reddy, O.V.S. 2012. Pectinase production from mango peel using Aspergillus foetidus and its application in processing of mango juice. Food Biotechnol. 26: $107-123$. 
Larrauri, J.A., Rupérez, P. \& Saura-Calixto, F. 1997. Mango peel fibres with antioxidant activity. Z. Lebensm Unters Forsch A 205: 39-42.

Luo, F., Lv, Q., Zhao, Y., Hu, G., Huang, G., Zhang, J., Sun, C., Li, X. \& Chen, K. 2012. Quantification and purification of mangiferin from Chinese mango (Mangifera indica L.) cultivars and its protective effect on human umbilical vein endothelial cells under $\mathrm{H}_{2} \mathrm{O}_{2}$-induced stress. Int. J. Mol. Sci. 13: 11260-11274.

Madhukara, K., Nand, K., Raju, N.R. \& Srilatha, H.R. 1993. Ensilage of mango peel for methane generation. Process Biochem. 28: 119-123.

Malviya, R., Srivastava, P., Bansal, M. \& Sharma, P.K. 2010. Mango peel pectin as a superdisintegrating agent. Journal of Scientific \& Industrial Research 69: 688-690.

Malviya,R.\& Kulkarni,G.T.2012.Extraction and characterization of mango peel pectin as pharmaceutical excipient. Polim. Med. 42: 185-190.

Mercadante, A.Z. \& Rodriguez-Amaya, D.B. 1998. Effects of ripening, cultivar differences and processing on the carotenoid composition of mango. J. Agr. Food Chem. 35: 262-265.

Mudaliyar, P., Sharma, L. \& Kulkarni, C. 2012. Food waste management-Lactic acid production by Lactobacillus species. International Journal of Advanced Biological Research 2: 34-38.

Ojokoh, A.O. 2007. Effect of fermentation on the chemical composition of mango (Mangifera indica L.) peels. Afr. J. Biotechnol. 6: 1979-1981.

Palmeira, S.M.V., Gois, L.M. \& Souza, L.D. 2012. Extraction of phenolic compounds from mango peels. Latin Am. Appl. Res. 42: 77-81.

Puravankara, D., Bohgra, V. \& Sharma, R.S. 2000. Effect of antioxidant principles isolated from mango (Mangifera indica L.) seed kernels on oxidative stability of buffalo ghee (butterfat). J. Sci. Food Agr. 80: 522-526.

Qin, L-J., Wang, Q. \& Wu, L-Y. 2007a. Stability of antimicrobial activities of mango (Mangifera indica L.) peel extracts. Guangxi Agricultural Sciences 4: 423-426.

Qin, L-J., Wu, Z. \& Wu, L-Y. 2007b. Preliminary study on antifungal activities of different extracts of the peel of mango (Mangifera indica Linnaeus). Chinese Journal of Tropical Agriculture 2: 21-25.

Ramteke, R.S. \& Eipeson, W.E. 1997. Effect of additives on the stability of mango aroma concerntrate during storage. J.Food Sci. Technol. 34: 195-199.

Rashad, M.M., Moharib, S.A. \& Jwanny, E.W. 1990. Yeast conversion of mango waste or methanol to single cell protein and other metabolites. Biol. Waste. 32: 277-284.

Reddy, L.V., Reddy, O.V.S. \& Wee, Y.J. 2011. Production of ethanol from mango (Mangifera indica L.) peel by Saccharomyces cerevisiae CFTRI101. Afr. J. Biotechnol. 10: 4183-4189.

Rehman, Z.U., Salariya, A.M., Habib, F. \& Shah, W.H. 2004. Utilization of mango peels as a source of pectin. Jour. Chem. Soc. Pak. 26: 73-76.

Ruiz, C., Ramirez, C., Gutiérrez de Piñeres, Ángulo, M. \& Hedreira, J. 2011. Obtaining and characterization of mango peel powder and its use as a source of fiber and a functional ingredient in natural yogurt. Proceedings of the $11^{\text {th }}$ International Congress on Engineering and Food (ICEF11). http://www.icef11.org/content/papers/fpe/FPE1195.pdf

Saravanan, P., Muthuvelayudham, R. \& Viruthagiri, T. 2012. Application of statistical design for the production of cellulase by Trichoderma reesei using mango peel. Enzyme Research 2012: Article ID 157643.

Sogi, D.S., Siddiq, M., Greiby, I. \& Dolan, K.D. 2013. Total phenolics, antioxidant activity, and functional properties of 'Tommy Atkins' mango peel and kernel as affected by drying methods. Food Chem. 141: 2649-2655.

Somayaji, D., Padshetty, N.S. \& Nand, K. 2001. Recycling of mango-peel waste for biogas production. Asian J. Microbiol. Biotechnol. Environ. Sci. 3: 339-341.

Somda, M.K., Savadogo, A., Quattara, C.A.T., Quattara, A.S. \& Traore, A.S. 2011. Thermotolerant and alcohol-tolerant yeasts targeted to optimize hydrolyzation from mango peel for high bioethanol production. Asian Journal of Biotechnology 3: 77-83.

Sruamsiri, S. \& Silman, P. 2009. Nutritive value and nutrient digestibility of ensiled mango by-products. Maejo Int. J. Sci. Technol. 3: 371-378.

Tunchaiyaphum, S., Eshtiaghi, M.N. \& Yoswathana, N. 2013. Extraction of bioactive compounds from mango peels using green technology. International Journal of Chemical Engineering and Applications 4: 194-198.

Varakumar, S., Sudheer Kumar, Y. \& Vijaya Sarathi Reddy, O. 2011. Carotenoid composition of mango (Mangifera indica L.) wine and its antioxidant activity, J. Food Biochem. 35: 1538-1547.

Varakumar, S., Naresh, K. \& Reddy, O.V.S. 2012. Preparation of mango (Mangifera indica L.) wine using a new yeastmango peel immobilized biocatalyst system. Czech J. Food Sci. 30: 557-566.

Walia, N.K., Bedi, S.S., Kundu, K. \& Karmakar, R. 2013. Production of bioethanol from mango peel. International Journal of Engineering Research \& Technology 2: 1-7.

Wyman, Ch.E. 2001. Twenty years of trials, tribulations, and research progress in bioethanol technology. Appl. Biochem. Biotech. 91: 5-21.

Zgórka, G. \& Kawka, S. 2001. Application of conventional $\mathrm{UV}$, photodiode array (PDA) and fluorescence (FL) detection to analysis of phenolic acids in plant material and pharmaceutical preparation. J. Pharm. Biomed. Anal. 24: 1065-1072.

Pradeep Puligundla \& Chulkyoon Mok

Department of Food Science \& Biotechnology

Gachon University, Seongnam 461-701

South Korea

Sang Eun $\mathrm{Oh}^{*}$

Bioenergy Laboratory, Department of Biological Environment Kangwon National University, Chuncheon 200-701

South Korea

Vijaya Sarathi Reddy Obulam,

Department of Biochemistry

Sri Venkateswara University, Tirupati 517502

India

*Corresponding author; email: ohsangeun@kangwon.ac.kr

Received: 19 November 2013

Accepted: 15 May 2014 